\title{
A Look at 2017 \\ Takeaway Points from the State of the Climate Supplement
}

\author{
G. Hartfield, J. Blunden, and D. S. Arndt
}

\begin{abstract}
The following salient events and trends are reported upon in greater depth in the State of the Climate in 2017, the supplement to this issue of BAMS. Figures shown here are drawn from the supplement and are not cited in the text below.
\end{abstract}

GLOBAL CLIMATE. The dominant greenhouse gases released into Earth's atmosphere-carbon dioxide, methane, and nitrous oxide-increased once again in 2017, reaching new record highs. The annual global average carbon dioxide concentration at Earth's surface for 2017 was $405.0 \pm 0.1 \mathrm{ppm}$. This was $2.2 \mathrm{ppm}$ greater than 2016 amounts and was the highest in the modern atmospheric measurement record and in ice core records dating back as far as 800,000 years. The global growth rate of carbon dioxide has nearly quadrupled since the early 1960s. The rise in globally averaged levels of methane from 2016 to 2017 was $6.9 \pm 0.9 \mathrm{ppb}$, and the mean global atmospheric nitrous oxide levels rose $0.9 \mathrm{ppb}$ from 2016 to 2017. Both increases were comparable to the average yearly growth rate of each gas over the last 10 years.

Global surface temperatures were $0.38^{\circ}-0.48^{\circ} \mathrm{C}$ above the 1981-2010 average, depending upon the dataset used. This places 2017 as the second or third

AFFILIATIONS: HARTFIELD-NOAA/NWS Weather Forecast Office, Raleigh, North Carolina; BLUNDEN AND ARNDT-NOAA/ NESDIS/National Centers for Environmental Information, Asheville, North Carolina CORRESPONDING AUTHOR: Jessica Blunden, jessica.blunden@noaa.gov

DOI:10.II75/BAMS-D-18-0173.I

In final form 9 July 2018

For information regarding reuse of this content and general copyright information, consult the AMS Copyright Policy. warmest annual global temperature since records began in the mid- to late 1800s and makes it the warmest non-El Niño year on record, as El Niño-Southern Oscillation (ENSO) conditions were neutral through much of 2017, with weak La Niña conditions at the start and end. The four warmest years on record have occurred since 2014. Above Earth's surface, the annual globally averaged lower-tropospheric temperature (the bulk atmosphere below 10-km altitude) in 2017 was, depending on the dataset, $0.38^{\circ}$ to $0.58^{\circ} \mathrm{C}$ above the 1981-2010 mean. This was a decrease of more than $0.1^{\circ} \mathrm{C}$ from the 2016 record-high level. Similarly, the 2017 globally averaged lower stratospheric temperature was $0.2^{\circ} \mathrm{C}$ greater than its record-low 2016 value but still below normal, with an anomaly of approximately $-0.4^{\circ} \mathrm{C}$ (variation among datasets was $\pm 0.2^{\circ} \mathrm{C}$ ).

The year saw a wide swing of precipitation extremes, with some areas experiencing remarkable tropical and post-tropical cyclone precipitation, while others were affected by extended droughts. After a significant peak in global drought area in 2016, the drought area fell sharply in early 2017 before rising to above-average values once again later in the year. At least $3 \%$ of the land area was affected by extreme drought conditions in each month of 2017, and this is the fourth greatest monthly percentage of severe drought since 1950 (after 1984, 1985, and 2016). Severe drought conditions in British Columbia, Canada, contributed to its most extensive wildfire season on record. On the high end of the precipitation 


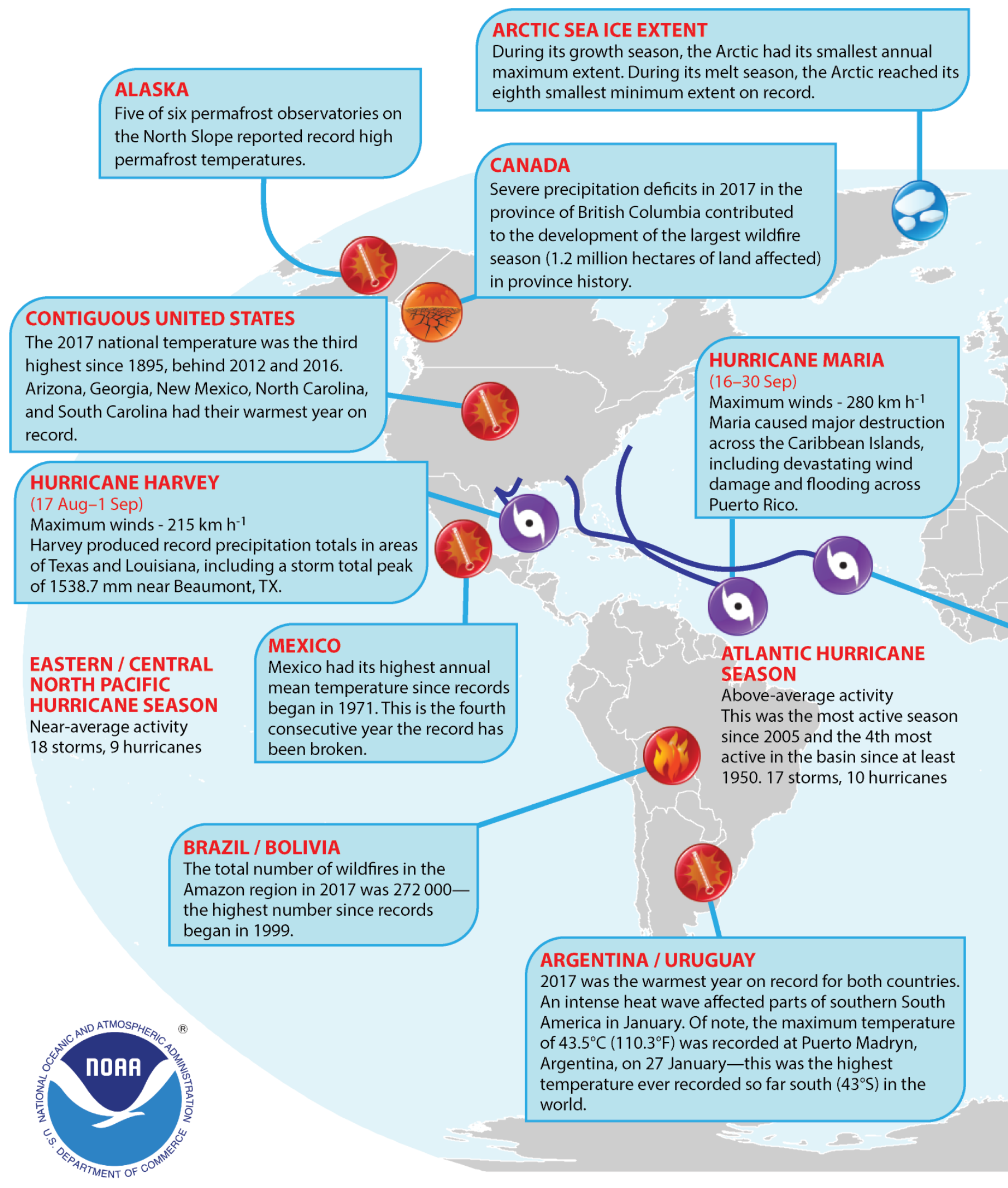

Geographical distribution of selected notable climate anomalies and events in 2017. 


\section{EUROPE}

Europe, as a whole, experienced its fifth warmest year on record. Individually, several countries ranked among their 5 warmest: Portugal (2nd), UK (5th), France (5th), Spain (1st), Ukraine (3rd), Israel (4th), and Bulgaria (1st).

\section{MIDDLE EAST}

Summer 2017 was extremely dry, with no precipitation at all for widespread regions in Lebanon, northern Syria, and Israel.

\section{HURRICANE IRMA}

(30 Aug-16 Sep)

Maximum winds - $295 \mathrm{~km} \mathrm{~h}^{-1}$ Irma affected Puerto Rico, the U.S. Virgin Islands, and Florida. It was the strongest tropical cyclone globally in 2017.

\section{SOUTH AFRICA}

2017 was the fourth warmest year on record since records began in 1951.

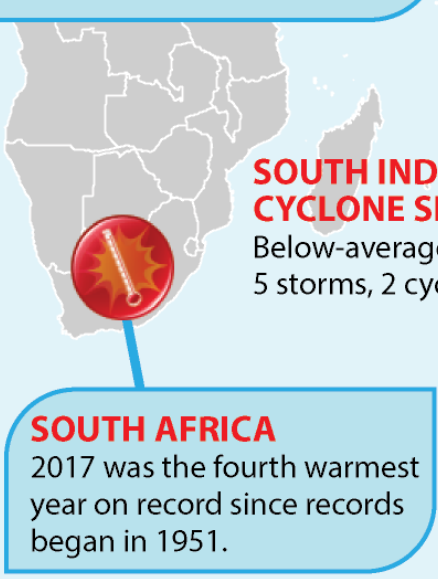

\section{RUSSIA}

Russia experienced its second wettest year on record (after 2013).
NORTH INDIAN OCEAN CYCLONE SEASON

Near-average activity 3 storms, 1 cyclones

\section{SOUTHEAST ASIA}

2017 was the fourth warmest year since records commenced in 1901.

\section{PAKISTAN}

On 28 May in Turbat, western Pakistan, the high of $53.5^{\circ} \mathrm{C}$ tied the all-time highest temperature ever recorded in Pakistan, and was the world record highest temperature for May.

\section{WESTERN PACIFIC OCEAN TYPHOON SEASON \\ Near-average activity}

26 storms, 12 typhoons

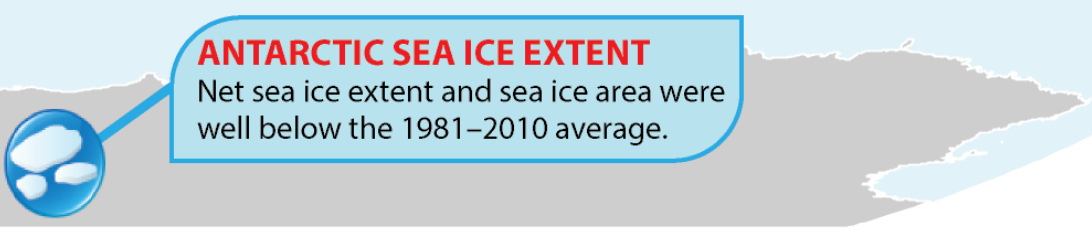

\section{AUSTRALIAN CYCLONE SEASON} Near-average activity 9 storms, 3 cyclones
SOUTH WEST PACIFIC OCEAN CYCLONE SEASON

Below-average activity 6 storms, 3 cyclones

\section{AUSTRALIA}

Experienced its third warmest year since national records began in 1910. Seven of Australia's ten warmest years on record have occurred since 2005.

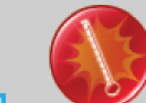

Please note: Material provided in this map was compiled from NOAA's NCEI State of the Climate Reports, the WMO Statement on the State of the Global Climate in 2017 (WMO-No. 1212), and authorship for this report. For more information visit: www.ncdc.noaa.gov/sotc. 


\section{Surface Temperature}

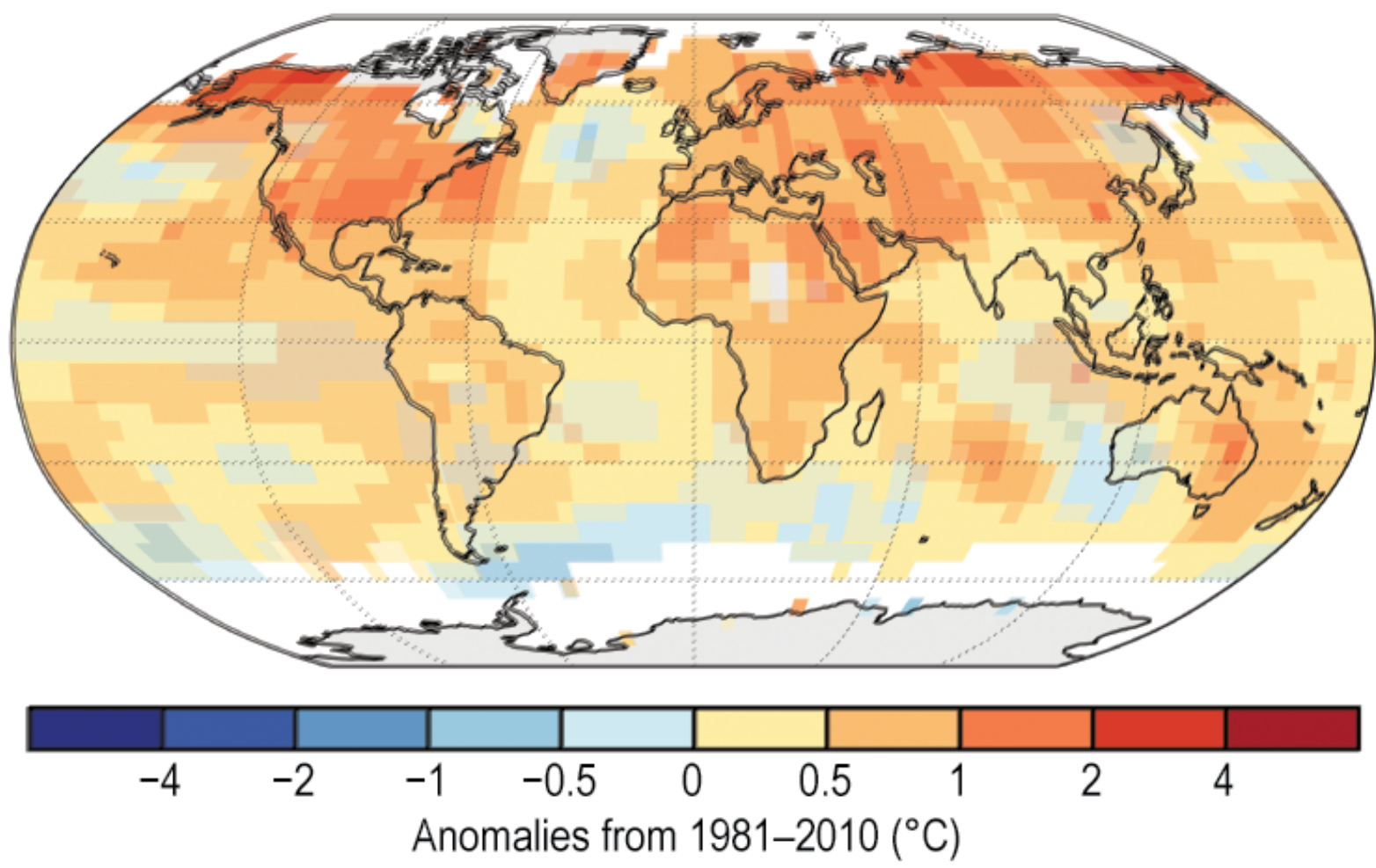

During 2017, much-warmer-than-average conditions were present across most of the world's land and ocean surfaces, with limited areas (parts of the North, central, and eastern Pacific Ocean; the southern Atlantic Ocean; eastern Indian Ocean; and a small area in western North America) experiencing near- to cooler-thanaverage conditions, as shown by European Centre for Medium-Range Weather Forecasts (ECMWF) interim reanalysis (ERA-Interim) 2-m surface air temperature annual anomaly map ( ${ }^{\circ} \mathrm{C}$, relative to the $198 \mathrm{I}-2010$ base period). (Plate 2. Ia in State of the Climate in 20I7; see discussion there in section 2bl.)

spectrum, Severe Tropical Cyclone Debbie (27 March-6 April) in Australia and New Zealand and Hurricane Harvey (25 August-1 September) in the United States produced unprecedented impacts from heavy rainfall.

GLOBAL OCEANS. While the global average sea surface temperature (SST) in 2017 was slightly below the 2016 value, the long-term trend remained upward, with the last three years seeing the three highest annual average SSTs on record. Variations existed among ocean regions. Compared to 2016, the sea surface in 2017 was mostly cooler in the tropical and subtropical oceans, while warming took place in the midlatitudes. The global average SST anomaly, relative to the 1981-2010 climatology, remained positive but decreased slightly from a record high of $+0.40( \pm 0.06){ }^{\circ} \mathrm{C}$ in 2016 to +0.34 $( \pm 0.06){ }^{\circ} \mathrm{C}$ in 2017.
Global mean sea level in 2017 was the highest annual average in the satellite altimetry era (since 1993), with values $77 \mathrm{~mm}$ above the 1993 average. Levels have risen year to year for six consecutive years and in 22 of the last 24 years. Regional variations were evident, with differences attributed to changes in trade wind strength and downwelling Ekman pumping, along with 2017's ENSO-neutral to weak La Niña conditions.

Oceanic heat content $(\mathrm{OHC}$ ) also rose on a global scale in 2017, with integrals of 0-700 - and 0-2000-m $\mathrm{OHC}$ reaching record highs. Using six global integral estimates and applying a linear trends fit, the 0-700-m OHC year-to-year gain from 1993 through 2017 ranged from $0.36( \pm 0.06)$ to $0.40( \pm 0.18) \mathrm{W} \mathrm{m}^{-2}$. Along the east coast of North America, SSTs, OHC, and sea level were all anomalously high in 2017, as they have generally been since at least 2009 . 


\section{Unprecedented Multiyear Coral Bleaching}

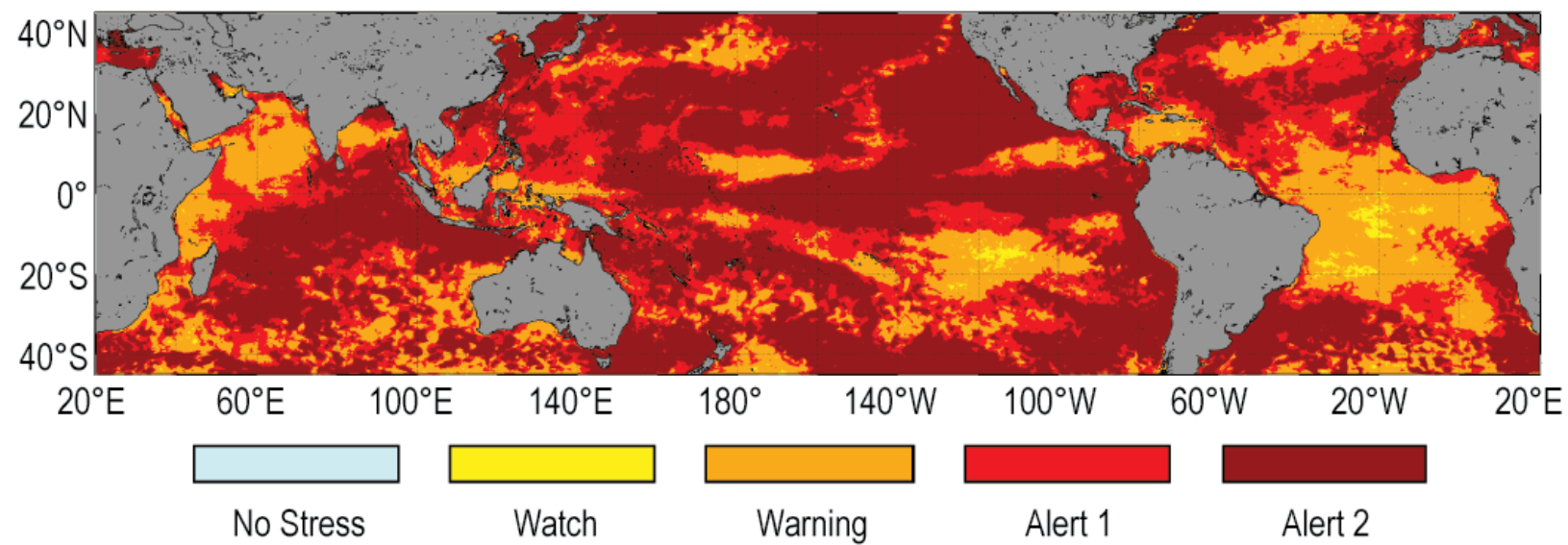

Coral reefs are a foundational element of the marine ecosystem. Widespread coral bleaching occurs when abnormally high SSTs coincide with high subsurface light levels, prompting the expulsion of beneficial algae by stressed corals. Severe or repeated bleaching can cause coral mortality (death). Mass bleaching, believed at one time to occur about once every 25-30 yr, now occurs about once every 6 yr and is expected to further accelerate as oceans warm. A global coral bleaching event, defined as mass bleaching across hundreds of kilometers or more in all three (Atlantic, Indian, Pacific) ocean basins, spanned 36 months from June 2014 through May 2017. This event was unprecedented in duration, scope, and the magnitude of damage to reefs, some of which experienced mortality in excess of $95 \%$. This map shows the maximum coral bleaching alert level for tropical and near-tropical waters during the period. (Figure SB3.I in State of the Climate in 20I7; see discussion there in Sidebar 3.2.)

\section{Regional Variability in Sea Level Rise}

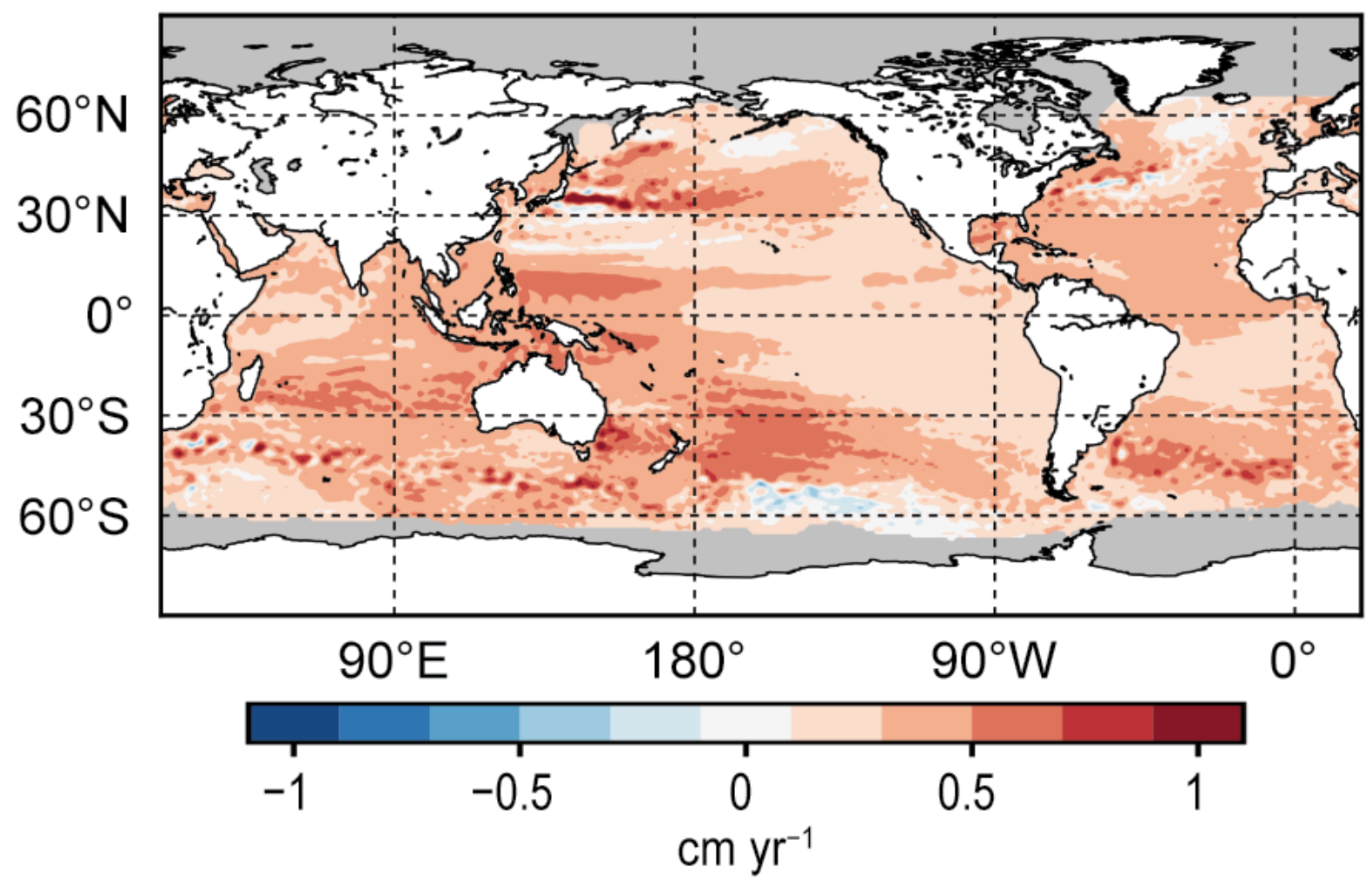

Linear trends show that the Indian and western Pacific Oceans have had the greatest large-scale sea level rise during the satellite altimetry era (since 1993). Increases of 3-7 $\mathrm{mm} \mathrm{yr}^{-1}$ translate to a sea level rise exceeding $100 \mathrm{~mm}$ during the period for parts of these regions. (Figure 3.15b in State of the Climate in 2017; see discussion there in section 3f.) 

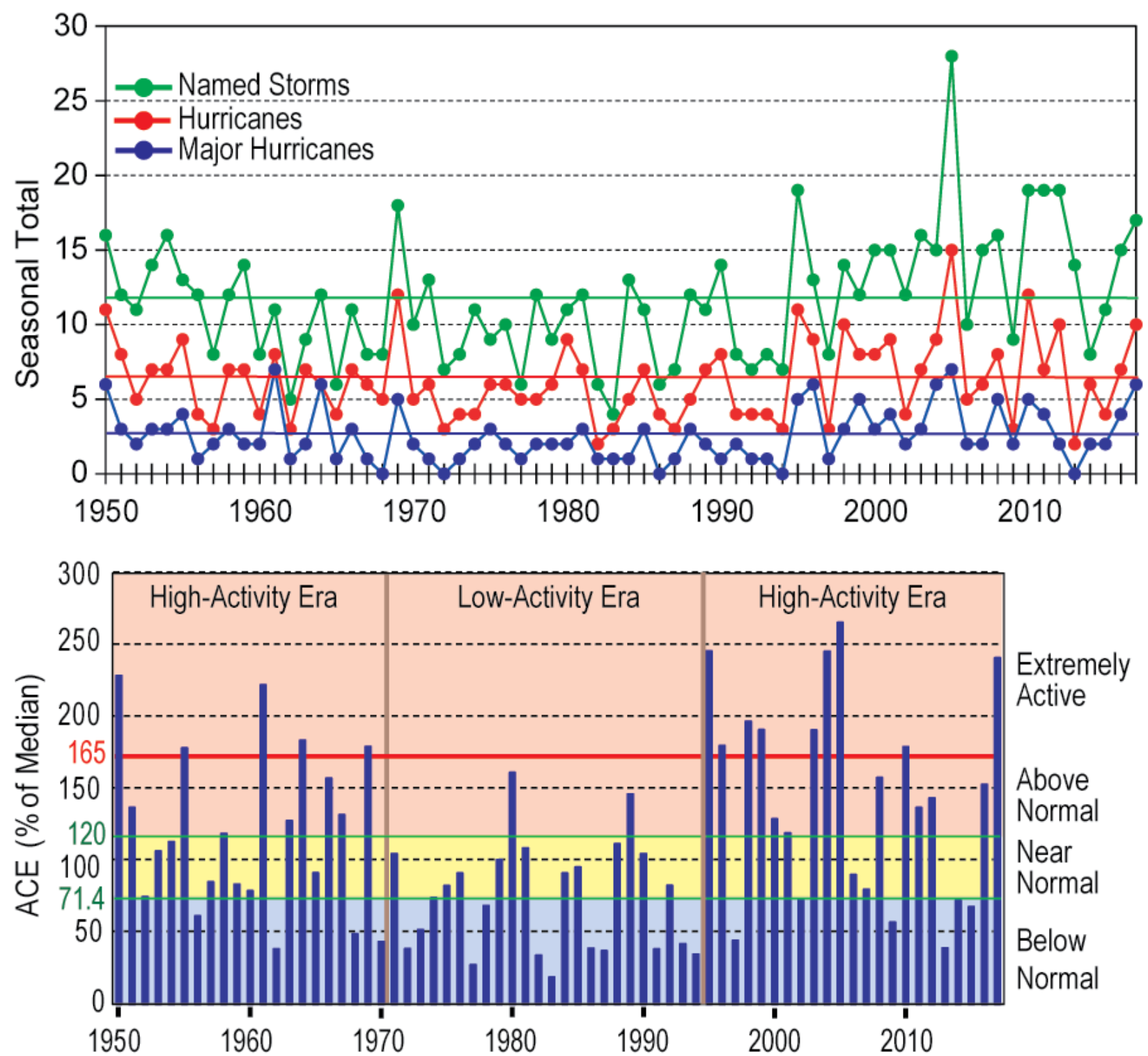

The profound tropical cyclone impacts experienced in the United States and the Caribbean during the 2017 hurricane season reflected the very active state of the Atlantic basin, as measured by the number of named and hurricane-strength storms, and in the accumulated energy associated with those storms. The high level of 2017 activity fits into a larger era of an active Atlantic basin, dating to the mid-1990s. (Figure 4.19 in State of the Climate in 20I7; see discussion there in section 4f2).

TROPICS. The 2017 average tropical temperatureland and ocean combined-was the third highest for the tropics $\left(20^{\circ} \mathrm{N}-20^{\circ} \mathrm{S}\right)$ since records began in 1880 , behind 2016 and 2015 . The year saw 85 named tropical storms, slightly above the 1981-2010 average of 82 but fewer than in 2016 (93 storms). Most basins saw near- to below-normal activity; however, activity in the North Atlantic basin (17 named storms, including 10 hurricanes and 6 major hurricanes) was above normal, making this the basin's seventh-most active season in the 164-yr record. The number of storms in the central and eastern North Pacific basins was well below normal, and the Southern Hemisphere had one of its quietest tropical cyclone seasons on record.

Globally, only three storms during the year reached Saffir-Simpson category 5 strength (wind speeds $\geq 137 \mathrm{kt}$ or $70.5 \mathrm{~m} \mathrm{~s}^{-1}$ ): Hurricanes Irma and Maria in the North Atlantic and Supertyphoon Noru in the western North Pacific. This is fewer than the number of category 5 storms in 2016 (four) and 2015 (eight). The North Atlantic was the only basin globally that featured above-normal accumulated cyclone 
energy (ACE), about $241 \%$ of its 1981-2010 median, making 2017 the most active North Atlantic season since 2005. The western North Pacific had less than half of its normal annual ACE, and the southern Indian Ocean 2016/17 seasonal ACE was about one-third of its 19812010 average.

THE ARCTIC. Average air temperatures in land areas above $60^{\circ} \mathrm{N}$ continued to increase in 2017, warming at a pace that was twice the rate of the rest of the world. The annual mean surface air temperature was the second highest since 1900 , trailing only 2016 , at $1.6^{\circ} \mathrm{C}$ above the 1981-2010 climatology. The autumn months (October-December 2017) saw a large area of extreme high temperature anomalies (greater than $+4^{\circ} \mathrm{C}$ ) across the central Arctic.

Sea ice extent continued to see low levels. On 7 March, the 2017 maximum extent of Arctic sea ice measured by satellite was $8 \%$ below the 1981-2010 mean, making it the record-lowest maximum extent in the 38-yr period of record. The September 2017 sea ice minimum was the eighth lowest on record, $25 \%$ smaller than the long-term average. Ten of the lowest sea ice extent minima on record have occurred in the last 11 years. Sea ice in the Arctic in recent years is new, thin, and vulnerable to breakup and melting, hastening the yearto-year drop in sea ice extent, while the areal coverage by old, thicker ice continues to diminish to a smaller portion of the total Arctic ice coverage.

In contrast to the record-breaking low sea ice extent, the spring snow cover extent (SCE) in 2017

\section{Sea Ice Retreat}

\section{Arctic Amplification Seen in Temperature}

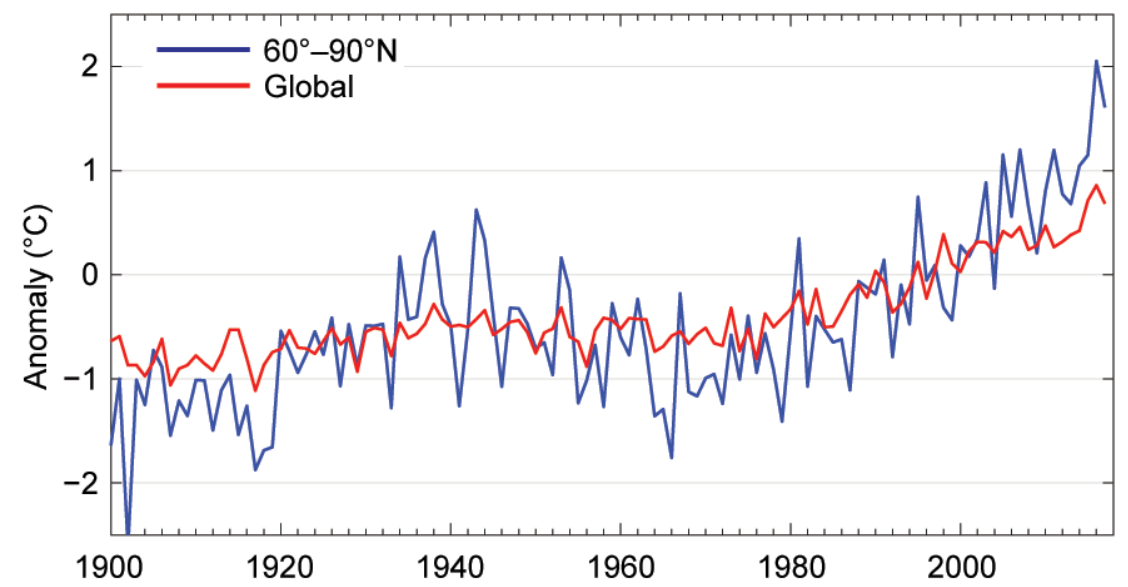

Arctic surface air temperatures (SATs) continue to rise more rapidly than the rest of the planet. This "Arctic amplification" is the result of feedback by additional warming factors like sea ice and snow cover retreat. (Figure 5.1 in State of the Climate in 2017; see discussion there in section $\mathbf{5 b}$.)

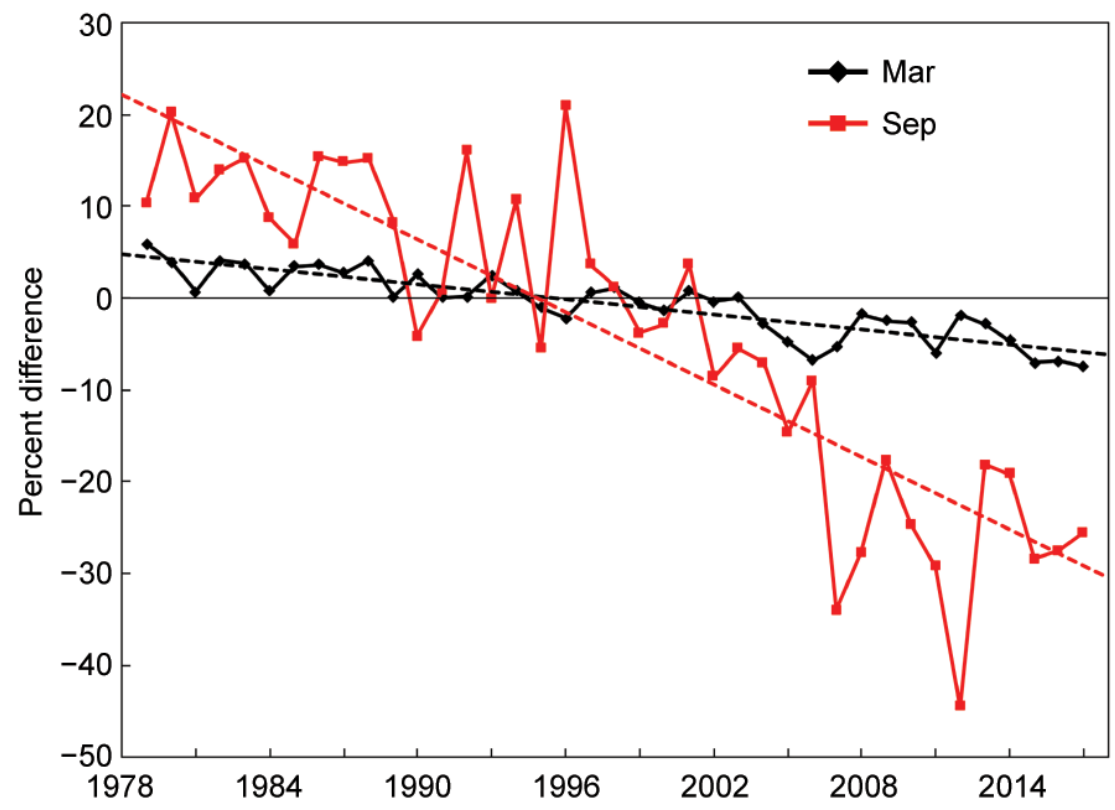

The annual Arctic sea ice extent cycle features growth through the winter months to an annual maximum extent typically occurring in March, followed by a decrease in ice extent during the melt season, which culminates in a September minimum. Over decadal time scales, with year-to-year variations, Arctic sea ice extent is shrinking throughout the calendar. The loss is more dramatic, comparatively, for the months surrounding the annual minimum compared to those surrounding the annual maximum. (Figure 5.8 in State of the Climate in 2017; see discussion there in section $5 \mathrm{dl}$.)

was not particularly low. For the first time in more than a decade, the spring SCE in the Eurasian Arctic was greater than the 1981-2010 average. While the SCE in the North American Arctic was less than the 


\section{Glaciers and Ice Sheets Continue to Lose Mass}

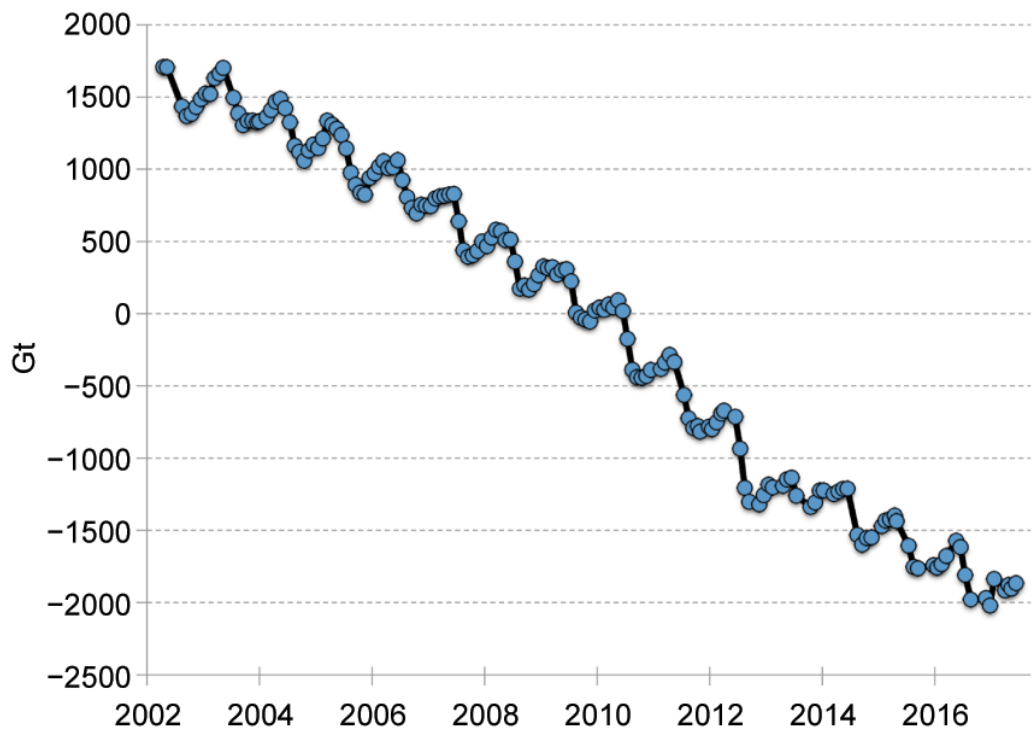

Roughly 3500 gigatons of the Greenland ice sheet melted or calved during the 2002-17 lifetime of Gravity Recovery and Climate Experiment (GRACE) satellite mass measurements. Worldwide, the decrease in glacial mass balance since 1980, which includes loss at the terminus and melt at the surface, represents the equivalent of a 22-m slab removed from the top of the average glacier. (Figure 5.12 in State of the Climate in 2017; see discussion there in sections $2 c 3$ and 5 e4.)

long-term mean, it was not as small as that measured in recent years. The moderation in Eurasian SCE in 2017 reflects a later-than-normal onset of snow melt, due in part to cooler spring air temperatures in that region, while across the higher latitudes of North America, a warmer-than-average spring led to a slightly earlier spring snow melt.

In 2017, the Greenland ice sheet rebounded from the dramatically low mass observed in 2016 . While rapid melting was noted in April, the maximum melt area during the 2017 summer (32.9\%) was below the 1981-2010 average maximum ice melt extent of 39.8\% and was the lowest melt area since 1996. As a result of this reduced melt, summer albedo was the third highest (after 2000 and 2013) since records began in 2000. The total loss of ice mass in Greenland in 2017 was close to the 2003-16 mean.

Following the warming trend of the air temperatures above it, the terrestrial permafrost continued to warm at record rates in 2017. Five of the six permafrost observatories on Alaska's North Slope indicated record warm permafrost temperatures. Other phenomena linked to higher air temperatures, including tundra greening and tundra browning, were also observed.

ANTARCTICA. Surface pressures and circulation patterns over the Antarctic continent are strongly correlated with other climate measures, including sea ice and precipitation. The year 2017 was noteworthy for its wide regional variations and anomalies in these characteristics. Positive pressure anomalies during January 2017 led to negative temperature anomalies of about $1^{\circ} \mathrm{C}$; however, the development of a deep low persisting from late austral summer through fall (February-May) produced much-above-average temperatures over West Antarctica, over three standard deviations above normal. The East Antarctic, by contrast, had record cold monthly mean temperatures in March.

Formation of a zonal wavenumber 3 pattern by wintertime (June-September) resulted in below-average temperatures across the continent, evident through the troposphere and stratosphere. East Antarctica saw record low monthly mean temperatures in June, while West Antarctica experienced its coldest anomalies in July and September, $2^{\circ}-4^{\circ} \mathrm{C}$ and $4^{\circ}-8^{\circ} \mathrm{C}$ below average, respectively.

The pendulum swung back with the development of positive anomalies of pressure and temperature starting in October, highlighted by a record warm October at Vostok station in East Antarctica. Temperatures across much of the continent averaged from slightly above to much above normal over the last few months of 2017, although the Ross Ice Shelf experienced below-average temperatures and a record low monthly mean surface pressure in November.

Sea ice extent remained low for most of 2017, well below the 1981-2010 average, including recordlow net sea ice extent from January through April. Throughout 2017 there were 130 days of record-low sea ice extent. On 1 March 2017, the sea ice extent fell to $2.1 \times 10^{6} \mathrm{~km}^{2}$, which was the lowest observed daily value in the continuous satellite record (since 1978).

The strong positive anomalies of air temperature over the West Antarctic coast early in the year contributed to elevated levels of seasonal melt extent and melt index, both of which were the second highest observed since 2005. The 2016/17 melt season was slightly longer than normal, signaling an aboveaverage melt year. 
The long-term (since the early 2000s) downward trend in annual Antarctic ozone hole area continued through 2017. The Antarctic ozone hole was the second smallest on record (since 1988), behind 2002, with an average area of 17.4 million $\mathrm{km}^{2}$ from 7 September to 13 October, the period during which the vast majority of stratospheric ozone is typically destroyed.

\section{REGIONAL CLIMATES.}

North America. After a very warm 2016, air temperatures were again above normal across North America in 2017, with Mexico experiencing its warmest year on record (since 1971) for the fourth year in a row. Canada had its 10th warmest year on record (since 1948), while the United States saw its third-warmest year since records began in 1895. Temperatures across the continental United States since 1970 are increasing at a rate of $0.3^{\circ} \mathrm{C}$ per decade. Annual precipitation was close to average across the United States and Mexico, with areal averages of $104 \%$ of normal and $99.4 \%$ of normal, respectively, although regional anomalies varied widely across the two countries. While portions of eastern Canada were wetter than average, much of central and western Canada saw near- to below-normal precipitation in 2017, including the driest summer on record over southern British Columbia, contributing to the longest and most-severe wildfire season in its history. The United States was impacted by 16

\section{Antarctic Polynya Reappears}

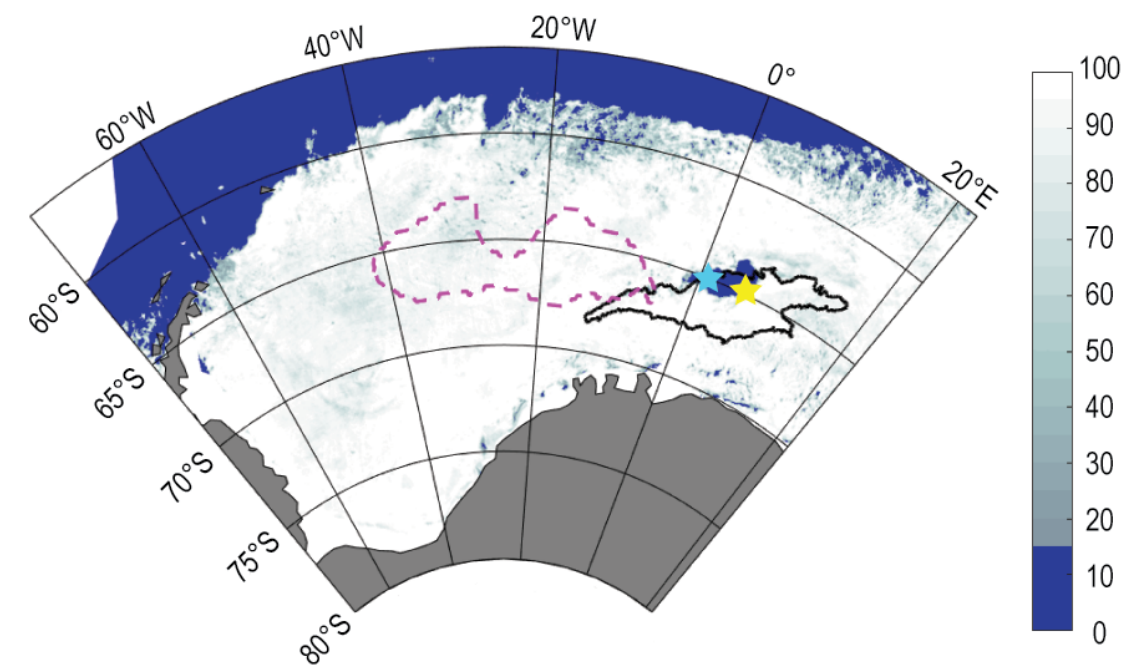

Polynyas are regions of open water within sea ice that allow for significant changes in the transfer of heat between ocean and atmosphere, and in density-based vertical ocean circulation. In 2016 a large polynya developed in the Maud Rise region of the Weddell Sea for the first time since the mid-1970s. A larger one developed in roughly the same region in late 2017 , represented by the enclave of blue (open waters) in the figure as of mid-October. Its largest 2017 extent, shortly before coalescing with the open ocean in late November, is represented by the solid black line. The magenta contour shows a 20 -yr mean location of the polynya based on model depictions. Researchers are analyzing profiling float data taken in the polynyas to investigate the drivers of, and the relationship between, these two twenty-first century occurrences. The vertical scale represents the calculated ice coverage, in percent, of each $\sim 6-\mathrm{km}$ grid box. (Figure SB6.Ib in State of the Climate in 20I7; see discussion there in Sidebar 6.I.)

\section{Record Mexican Temperatures}

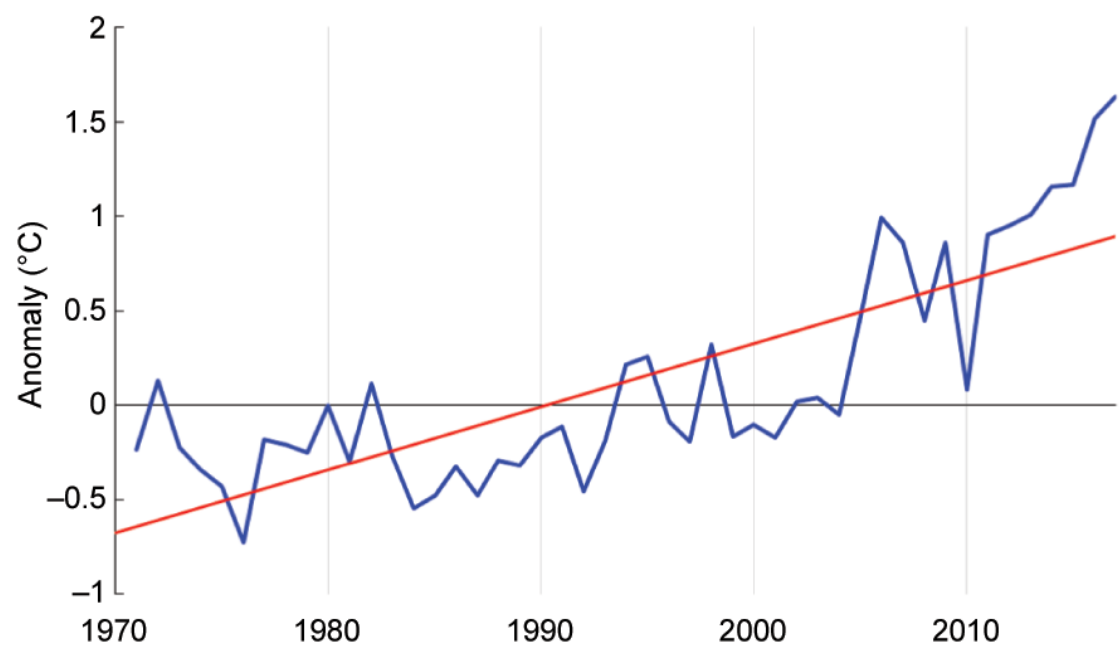

Mexico's nationally averaged temperature was its warmest on record for the fourth consecutive year, at more than $1.5^{\circ} \mathrm{C}$ above the $1981-2010$ average. The national temperature record for Mexico begins in 1970. (Figure 7.6 in State of the Climate in 2017; see discussion there in section $7 \mathrm{b3}$.) 


\section{Billion Dollar Disasters}

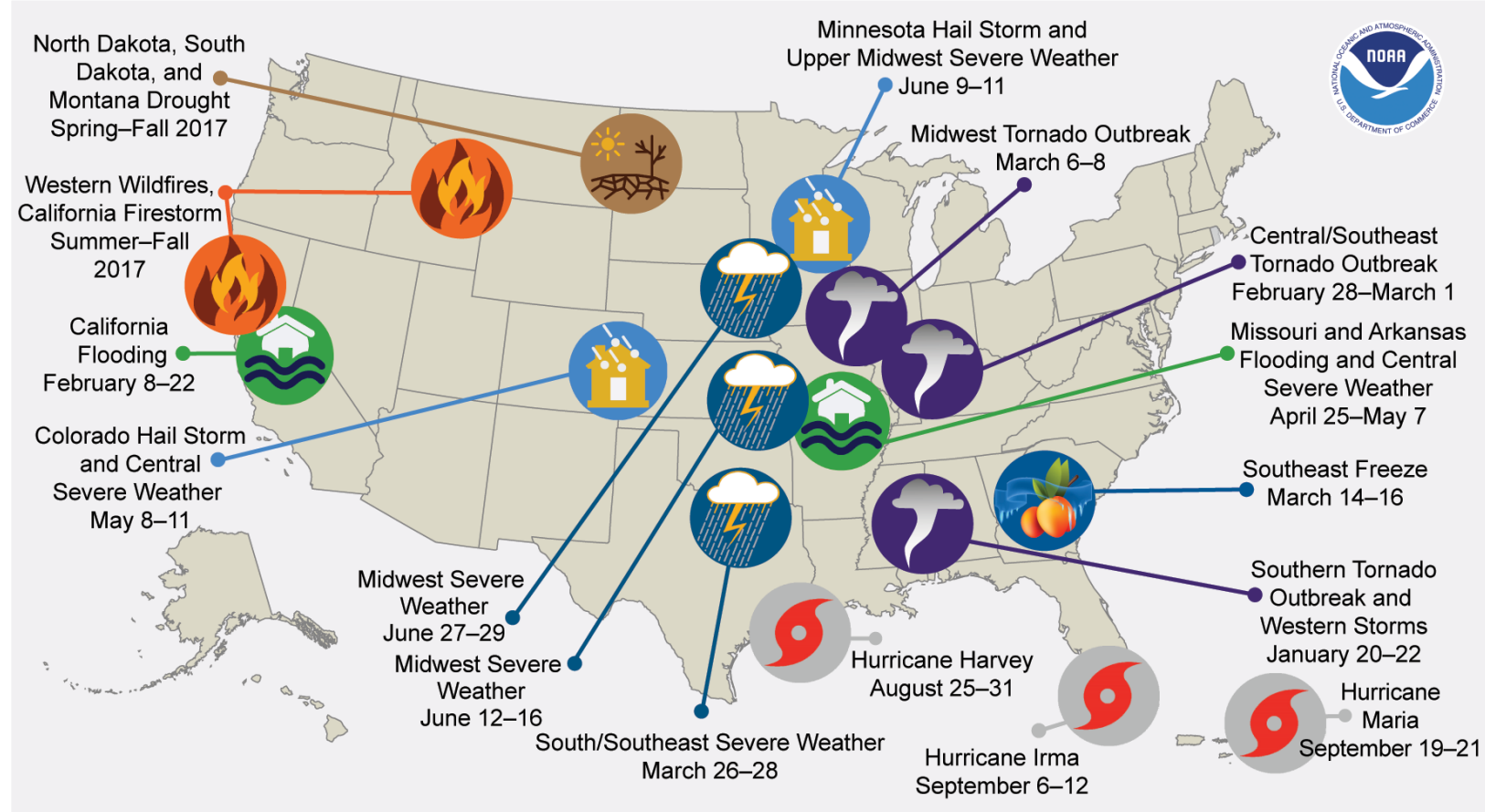

Each year, about three-fourths of total weather and climate related losses in the United States are concentrated in events that cause more than $\$$ I billion (U.S. dollars) in direct damages each. Sixteen disasters with loses of more than $\$ 1$ billion resulted in more than $\$ 300$ billion in direct losses in 2017 , making it the costliest year since at least 1980 for total losses from billion-dollar disasters. The total was driven largely by record losses associated with landfalling tropical cyclones and wildfire. (Figure 7.5 in State of the Climate in 2017; see discussion there in section $7 \mathrm{~b} 2$.)

weather and climate events that each caused over $\$ 1$ billion (U.S. dollars) in damages. Since records began in 1980, 2017 is tied with 2011 for the greatest number of billion-dollar disasters. Included in this total are the western U.S. wildfire season and Hurricanes Harvey, Maria, and Irma. Tornado activity in the United States in 2017 was above average for the first time since 2011, with 1400 confirmed tornadoes.

The Caribbean. Most reporting stations across the Caribbean recorded annual mean temperatures in 2017 that were near or above their 1981-2010 average, and several locations experienced annual maximum temperatures that were among their five highest on record. Mean temperatures in San Juan, Puerto Rico, for both February and September were their third highest since records began in 1898 .

Across much of the Caribbean, precipitation was normal to above normal, in tandem with above-average sea surface temperatures. Two reporting stations, one in Jamaica and the other in Martinique, saw their wettest year on record (since 1971). Port-au-Prince, in Haiti, however, had its driest year since records began in 1971.

\section{Caribbean warmer and wetter than normal}

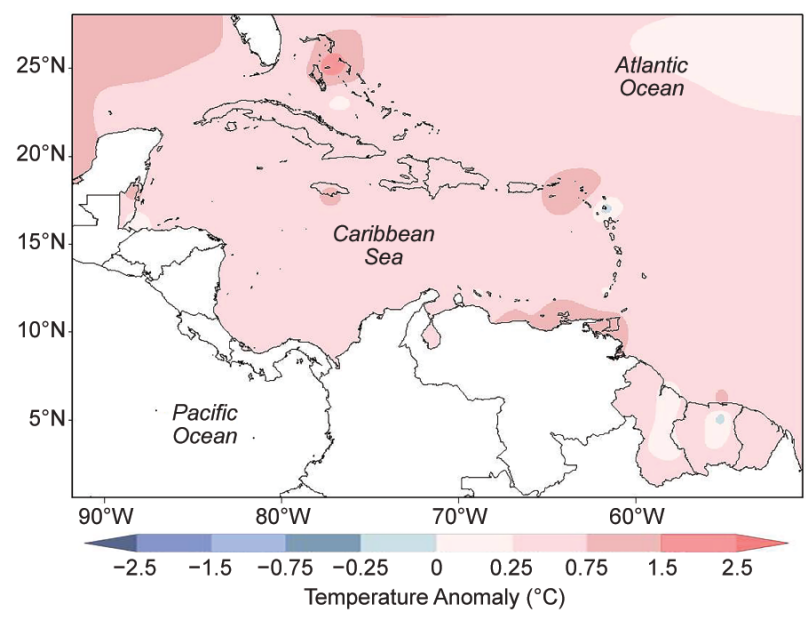

Above-normal temperatures dominated the Caribbean during 2017. Generally, the latter half of the year was warmer, relative to normal, than the first half. This late-year heat coincided with generally above-average precipitation totals, particularly for areas affected by the region's active tropical cyclone season. (Figure 7.10a in State of the Climate in 2017; see discussion there in section $7 \mathrm{c}$.) 
Much of the excessive Caribbean rainfall in 2017 can be attributed to tropical cyclones, including Hurricanes Irma, Jose, and Maria, which crossed the region over a two-week period. Largely due to these three hurricanes, the ACE index for September 2017 was the highest for any month in the Atlantic basin since 1851 . Hurricane Irma had peak sustained winds of $160 \mathrm{kt}$ and was responsible for destroying much of the infrastructure of the island of Barbuda. Hurricane Maria arrived just two weeks later, making landfalls on Dominica and Puerto Rico. Maria devastated Puerto Rico, defoliating or uprooting countless trees, destroying the electrical grid, damaging most structures, and producing catastrophic flash flooding. María has been classified as the third costliest U.S. tropical cyclone on record (after 2015's Katrina and 2017's Harvey), with $\$ 90$ billion (U.S. dollars) in damages across Puerto Rico and the U.S. Virgin Islands, and it was the strongest hurricane to impact Puerto Rico since 1928.

South America. Much of South America saw abovenormal temperatures in 2017, with anomalies near or exceeding $+1^{\circ} \mathrm{C}$. Precipitation was also higher than the 1981-2010 average across most areas. The warm and wet year across northern portions of South America can be attributed in part to warming of sea surface temperatures in the eastern equatorial Pacific during the first few months of 2017.

In Ecuador, torrential rains in February-April produced deadly flooding and landslides and set precipitation records. A landslide in Colombia in March killed more than 250 people. Flash flooding and landslides in May in northeast Brazil affected over 8400 families and left more than 16,500 homeless.

In contrast, central Argentina and central Chile were very dry during the beginning of 2017, leading to a severe drought that fostered the development of wildfires. These dry conditions were exacerbated by a massive heat wave in January lasting over two weeks. The temperature reached $43.4^{\circ} \mathrm{C}$ on $27 \mathrm{Janu}-$ ary at Puerto Madryn, the highest temperature ever recorded so far south $\left(43^{\circ} \mathrm{S}\right)$ anywhere in the world.

Africa. Air temperatures were above normal across most of Africa in 2017, with the exception of small areas in western and southern Africa. The Gambia reported an annual mean maximum temperature of $35.6^{\circ} \mathrm{C}$, about $4.5^{\circ} \mathrm{C}$ above normal. South Africa had its fourth highest annual mean temperature since records began in 1951. The Mascarenes archipelago, consisting of Réunion, Mauritius, and Rodrigues, experienced its warmest

\section{South American Temperature}
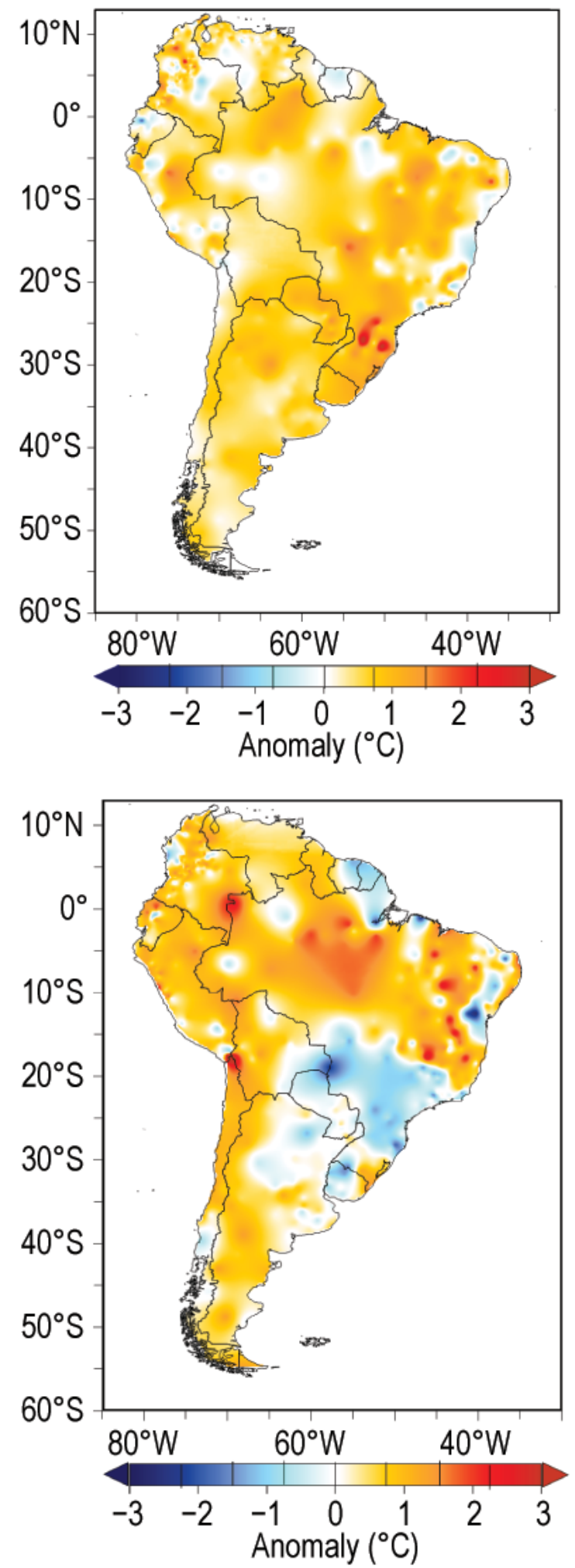

South America, on average, was warmer than normal during 2017, with Argentina and Uruguay recording their warmest years since records began in 1961. (Figure 7.1I in State of the Climate in 2017; see discussion there in section $7 \mathrm{~d}$.) 
year on record, due in part to highly positive sea surface temperatures anomalies across the region.

Wetter-than-average conditions were noted in most areas, although equatorial and southern Africa between $10^{\circ}$ and $20^{\circ} \mathrm{S}$ saw below-normal rainfall. Heavy rainfall and flooding were reported in many locations across the continent, including heavy downpours in February and December in Morocco and during August and September in Nigeria, The Gambia, and Niger. Alexandria, Egypt, recorded rainfall of $50 \mathrm{~mm}$ on 21 April, the highest 24-hour rainfall in Egypt during 2017.

Tropical cyclones impacted Mozambique, Zimbabwe, Réunion Island, and Madagascar. Cyclone Dineo in February left significant flood-related damage in southern Mozambique and Zimbabwe. Cyclone Carlos passed just off the coast of Réunion, causing agricultural losses of up to $\$ 4.9$ million (U.S. dollars). Cyclone Enawo made landfall on Madagascar in March, killing 81 people, injuring 250, and causing significant flooding.

Europe and the Middle East. The annual land surface temperature for Europe was the fifth highest in the record dating to 1851 , with a $+1.3^{\circ} \mathrm{C}$ departure from the 1961-90 average; the five warmest years for the continent have all occurred since 2011. Winter 2016/17 was exceptionally mild over Scandinavia, with temperature anomalies reaching more than $+4^{\circ} \mathrm{C}$. During long-lasting foehn winds in January, a daily mean temperature of $13.8^{\circ} \mathrm{C}$ was measured at station Sunndalsøra (Norway) on 25 January, which was the highest daily mean temperature ever recorded in January by a weather station in Norway and is a value more commonly measured around the beginning of July.

Above-normal 500-hPa height anomalies situated over central Europe led to the warmest spring on record in Spain. Conversely, April and May temperatures were well below normal in northwest Russia and northern Scandinavia, contributing to the greatest May snow cover extent in this area since 1985.

During summer, a high pressure bridge brought temperature anomalies as high as $+5^{\circ} \mathrm{C}$ to Italy and the Balkan states (former Yugoslavia) along with dry weather, with precipitation totals as low as $20 \%$ of normal. Italy in particular experienced a massive heat wave with record-breaking temperatures and extreme drought.

It was the second driest year for Spain (since 1965) and third driest for Portugal (since 1931). Portugal's average precipitation in September was just $5 \%$ of the 1971-2000 normal. In many places, no precipitation was measured at all. This was followed by the driest October of the last 20 years, with strong winds due to ex-Hurricane Ophelia that prevented the extinguishing of fires in both Portugal and Spain where at least 41 people were killed in wildfires. Ash from the fires was transported as far as the United Kingdom, where yellow skies and a red sun were reported.

Multiple heat waves in July were responsible for extreme temperatures in Cyprus, Jordan, and Israel. July 2017 tied with 2012 as the warmest July in Israel since the beginning of records, with average daily temperatures $2^{\circ}$ to $2.5^{\circ} \mathrm{C}$ above normal. During the first half of the month, an intense heat wave hit Croatia, drying out the plant cover, which led to the outbreak of a wildfire on 17 July with a $40-\mathrm{km}$-long fire front at its maximum, it was one of the biggest wildfires in Croatian history.

Asia. Annual mean temperatures for 2017 were above average across most of Asia. Russia observed its fourth warmest year on record, including a record warm March $\left(6.03^{\circ} \mathrm{C}\right.$ above normal). China and Hong Kong each had their third warmest year on record, while Mongolia reported its second warmest and India its fourth warmest. South Korea's average temperature in May was $1.5^{\circ} \mathrm{C}$ above normal, marking the fourth consecutive year of a new record-high May temperature.

In China, Typhoons Nesat and Haitang landed successively on the coast of Fuqing city in Fujian Province during 30-31 July, and four typhoons hit the Grand Bay area of Guangdong-Hong Kong-Macau from June to October. As Tropical Cyclone Hato headed toward Hong Kong, the subsidence effect ahead of its circulation brought oppressive heat to the territory on 22 August, with the temperature at the Hong Kong Observatory soaring to an all-time high of $36.6^{\circ} \mathrm{C}$.

In April, Larkana, a city in the southern province of Sindh, Pakistan, experienced a record maximum temperature of $51.0^{\circ} \mathrm{C}$ on 20 April. On 28 May, Turbat, in western Pakistan, recorded a temperature of $53.5^{\circ} \mathrm{C}$, tying the all-time highest temperature last recorded in Moen Jo Daro, Pakistan, on 26 May 2010. Heat wave conditions across much of India in late May claimed the lives of about 100 people in the state of Telangana. However, the loss of lives in 2017 was much less than in the previous years due to timely heat wave warnings and heat wave action plans initiated by the government.

The East Asian summer monsoon rainfall was weaker than normal, while the Indian summer monsoon rainfall was near normal; however, intraseasonal convective activity varied greatly in the monsoon 
regions. Overall, flooding rains and landslides during the monsoon season claimed around 800 lives across India. Portions of Sri Lanka received $300-500 \mathrm{~mm}$ of rain in a $24-\mathrm{h}$ period in late May, causing widespread flooding.

Oceania. Australia observed its third warmest year on record. Exceptional warmth affected large parts of eastern Australia from late December 2016 into February 2017. Records were set in southeastern Australia and southern Queensland for consecutive warm days or nights, or for the total number of warm days or nights during January. A heat wave in September broke temperature records across eastern Australia, while a second heat wave broke duration records in Victoria and Tasmania. New Zealand reported its fifth warmest year since its records began in 1909. Warm temperatures seen in November and December were likely influenced by synoptic patterns that also contributed to the exceptional warmth experienced across southeast Australia and the Tasman Sea.

Flooding affected large areas of the east coast of Australia in March. This flooding resulted from thunderstorms in New South Wales and Victoria during the middle of the month and from Severe Tropical Cyclone Debbie at the end of the month. Debbie also caused widespread wind damage in Queensland and northeastern New South Wales. In New Zealand the impact from Debbie led to several one-day rainfall records for the month across the Bay of Plenty, which contributed to severe flooding in parts of the region.

In the southwest Pacific, precipitation totals for 2017 were as low as 50\% of average in Nauru and the Gilbert Islands. These dry conditions were an extension of a drought event that began during the second half of 2016. Low rainfall from late 2016 through September 2017 resulted in drought emergencies in most of the atolls in the northern Republic of the Marshall Islands. Loss of potable water sources required emergency shipments of bottled water, reverse osmosis systems, emergency food supplies, and public health and hygiene assistance. New Caledonia experienced agricultural and hydrological droughts in the second half of 2017, leading to restrictions on drinking water and fires that destroyed vast areas of vegetation, including primary forests, despite a territory-wide fire ban.

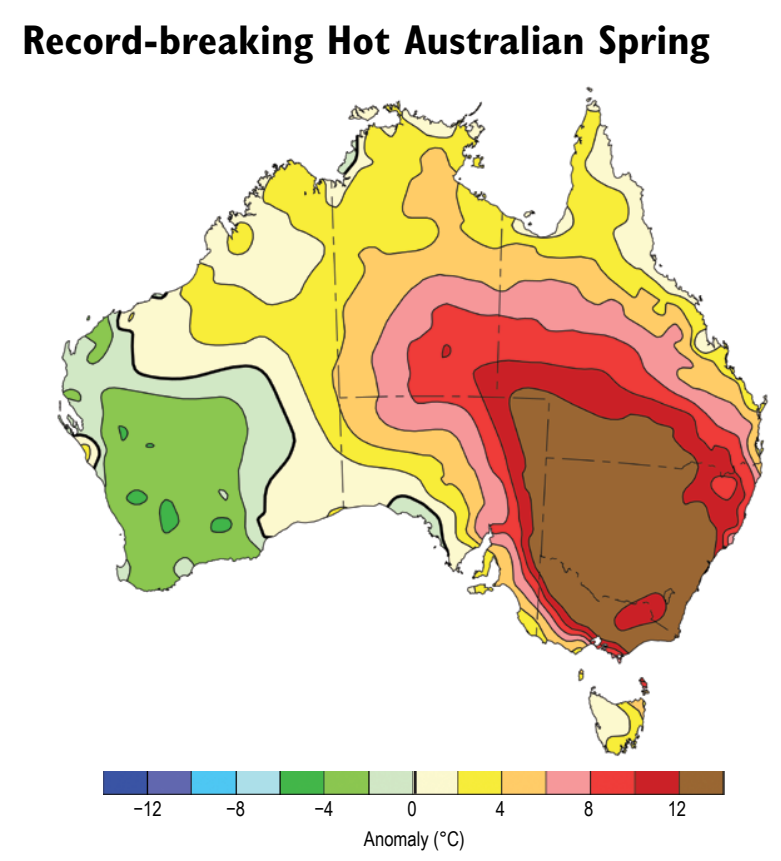

Eastern Australia experienced unprecedented heat in September; 22 September was Australia's warmest September day on record, although the highest local temperatures were observed on 23 September, when maximum temperatures were more than $12^{\circ} \mathrm{C}$ above the 1981-2010 average across much of the mainland southeast. Several sites in New South Wales reached $40^{\circ} \mathrm{C}$, the first such occurrences in the state during September; in Victoria, Mildura set a state record for September reaching $37.7^{\circ} \mathrm{C}$. (Figure SB7.6 in State of the Climate in 20I7; see discussion there in Sidebar 7.4.) 


\section{NEW SIGNIFICANTLY REVISED TEXIBOOK}

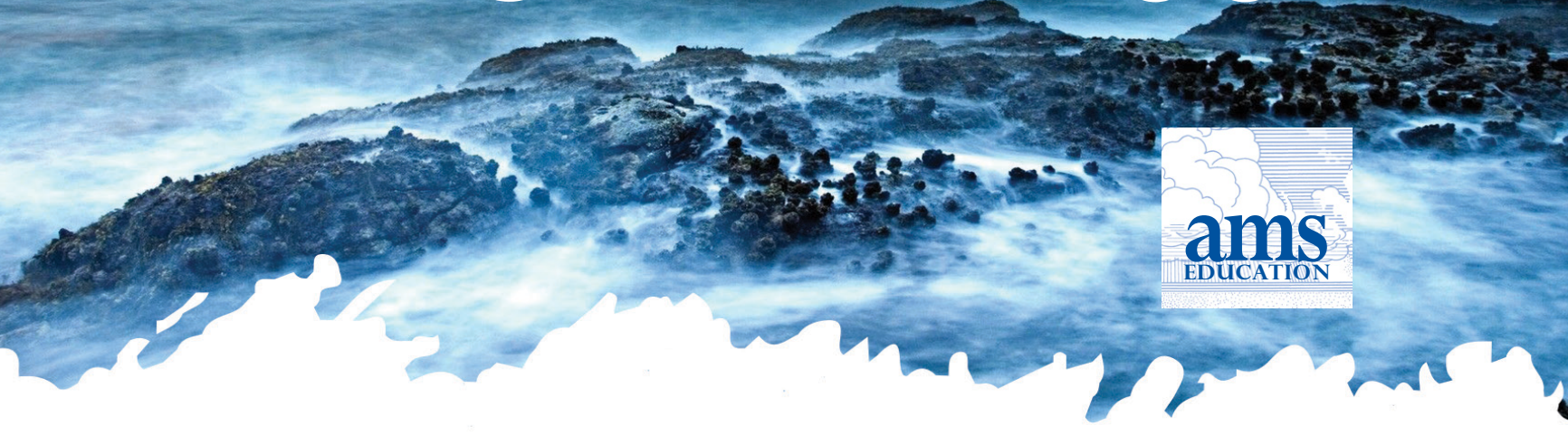

AMS Ocean Studies is an introductory, undergraduate-level curriculum package developed, licensed, and nationally implemented by the American Meteorological Society. AMS Ocean Studies consists of the new Ocean Studies: Introduction to Oceanography textbook, investigations manual, RealTime Ocean Portal, and course management system-compatible files. The $4^{\text {th }}$ edition Ocean Studies textbook underwent a major revision with significant updates to content and imagery. It is authored by Douglas $A$. Segar, Stacy W. Kish, and Elizabeth W. Mills, and includes 15 chapters exploring the world ocean from an Earth system perspective.

Instructors can use these materials in combinations that cater to face-to-face or online lecture or laboratory courses. Explore the Introductory Chapter of Ocean Studies at ametsoc.org/OceanTextbook
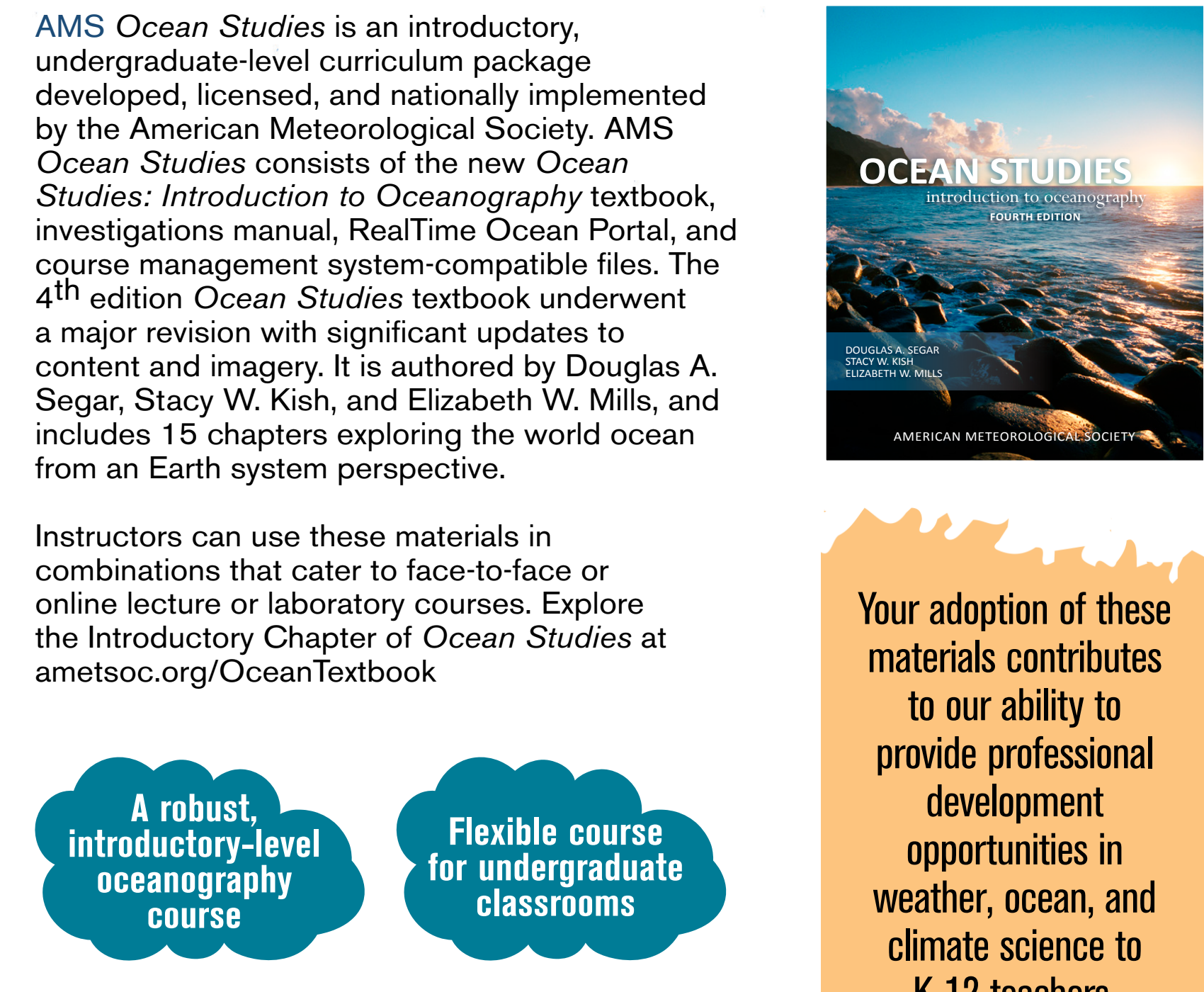

Your adoption of these materials contributes to our ability to provide professional development opportunities in weather, ocean, and climate science to $\mathrm{K}-12$ teachers.

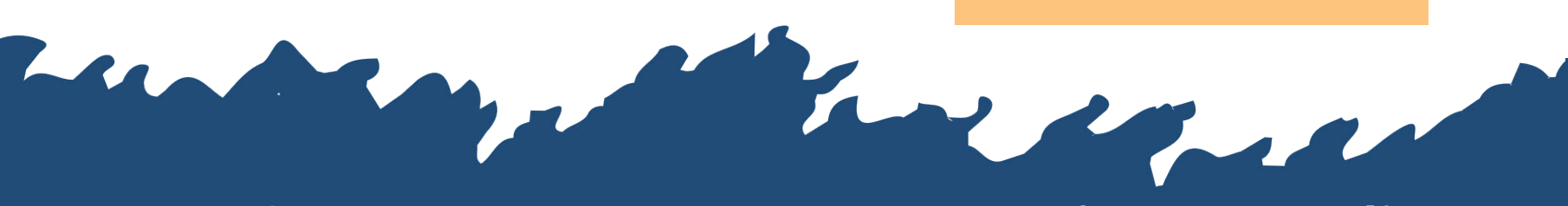

